\title{
Perbandingan Pengaruh Latihan Lari Melewati Bilah Dengan Latihan Lari Mengangkat Paha Terhadap Peningkatan Power Tungkai Pada Siswa
}

\author{
Dede Iman Suhendra \\ Program Studi Pendidikan Jasmani, Universitas Galuh Ciamis
}

\begin{abstract}
ABSTRAK
This study aims to determine whether there was a difference in the effect of running through the bar with running exercise lifting the thighs on the increase in leg power in students of Junior High School 3 Kawali. In accordance with the research objectives above, the authors use the experimental method. The population and sample of this study were 58 male students of class VIII Junior High School 3 Kawali, and from this population a part of which was taken to be the sample by as many as 30 students using random techniques. The research used as data collector is the standing broad jump test. The results of data processing in hypothesis testing are as follows; 1. Running through blades has a significant effect on increasing leg power in students of Junior High School 3 Kawali. This was proven by the results of the research, which shows that the training to run through the bar has a value of $\mathrm{t}$ count 3.06 greater than the $\mathrm{t}$-table (1.70) at a confidence level of 0.05 with $\mathrm{dk}=\mathrm{n} 1+\mathrm{n} 2-2=28$. 2. Running exercise to lift thighs has a significant effect on increasing leg power in students of Junior High School 3 Kawali. This was evidenced by the results of the study, the process of running training to lift the thighs has a $t$ value of 2.27 greater than the t-table (1.76) at a confidence level of 0.05 with $\mathrm{dk}=\mathrm{n} 1+\mathrm{n} 2-2=28.3$. No There is a difference in the effect of running through the bar with running lifting the thighs on the increase in leg power in Junior High School 3 Kawali students, where the results of the calculation and significance test using the two-party average test, namely the t-test, obtained a t-count of 1.35 which smaller than t-table (1.70) at a confidence level of 0.95 with $\mathrm{dk}=28$.
\end{abstract}

Keyword: Run out of the blade, run to lift the thighs, power the legs.

\begin{abstract}
Penelitian ini bertujuan untuk mengetahui apakah ada perbedaan pengaruh latihan lari melewati bilah dengan latihan lari mengangkat paha terhadap peningkatan power tungkai pada Siswa SMP Negeri 3 Kawali, sesuai dengan tujuan penelitian di atas, maka penulis menggunakan metode eksperimen. Populasi dan sampel penelitian ini adalah siswa putra kelas VIII SMP Negeri 3 Kawali yang berjumlah 58 orang, dari populasi tersebut diambil sebagian untuk dijadikan sampel dengan yaitu sebanyak 30 orang siswa dengan menggunakan teknik acak. Penelitian yang digunakan sebagai pengumpul data adalah tes standing broad jump, Adapun hasil pengolahan data dalam uji hipotesis diperoleh hasil sebagai berikut; 1 . Latihan lari melewati bilah memberikan pengaruh yang signifikan terhadap peningkatan power tungkai pada siswa SMP Negeri 3 Kawali. Hal ini terbukti dengan diperolehnya hasil penelitian, yang menunjukkan bahwa latihan lari melewati bilah memiliki nilai $\mathrm{t}$ hitung 3,06 lebih besar daripada t-tabel $(1,70)$ pada tingkat kepercayaan 0,05 dengan $\mathrm{dk}=\mathrm{n} 1+\mathrm{n} 2-2=$ 28. 2. Latihan lari mengangkat paha memberikan pengaruh yang signifikan terhadap peningkatan power tungkai pada siswa SMP Negeri 3 Kawali. Hal ini terbukti dengan hasil penelitian, proses latihan lari mengangkat paha memiliki nilai t hitung 2,27 lebih besar daripada t-tabel $(1,76)$ pada tingkat kepercayaan 0,05 dengan $\mathrm{dk}=\mathrm{n} 1+\mathrm{n} 2-2=28$. 3. Tidak terdapat perbedaan pengaruh antara latihan lari melewati bilah dengan lari mengangkat paha terhadap peningkatan power tungkai pada siswa SMP Negeri 3 Kawali, dimana hasil penghitungan dan uji signifikansi dengan menggunakan uji
\end{abstract}


rata-rata dua pihak yaitu uji-t, diperoleh t-hitung 1,35 yang lebih kecil dari t-tabel $(1,70)$ pada tingkat kepercayaan 0,95 dengan $\mathrm{dk}=28$.

Kata kunci: Lari melewati bilah, lari mengangkat paha, power tungkai.

\section{PENDAHULUAN}

Perkembangan dunia olahraga dari tahun ke tahun mengalami kemajuan, kemajuan tersebut ditandai dengan kualitas penampilan dan prestasi yang dicapai atlet yang berlaga diberbagai arena kejuaraan duni sekarang yang makin mengagumkan. Perkembangan di bidang olahraga tersebut merupakan sebuah tantangan bagi suatu Negara yang sedang berkembang, termasuk negara kita Indonesia. Ketertinggalan dalam pembinaan dan kecanggihan peralatan olahraga, permasalahan tersebut diperlukan adanya usaha-usaha manusianya untuk meningkatkan kemampuan berolahraga. Usaha-usaha manusia ini berupa latihan yang mengarah pada latihan fisik, teknik, mental dan taktik.

Latihan kondisi fisik memegang peranan yang sangat penting dalam sebuah program latihan atlet. Harsono (2001:4) menjelaskan bahwa; "Kalau kondisi fisik atlet baik, maka dia akan lebih cepat pula menguasai teknik-teknik gerakan yang dilatihkan". Karakteristik permainan dalam cabang olaharaga olahraga tertentu ada teknik yang menuntut untuk melakukan gerakan loncatan, lompatan dan tendangan yang kuat. Komponen-komponen yang menunjang keberhasilan dalam pencapaian suatu kemenangan dalam olahraga harus dilatih dan meningkatkan kemampuanny. Setiap peningkatan kemampuan teknik, taktik, dan mental harus didahului oleh peningkatan kemampuan faktor fisik yang merupakan penentu keberhasilan peningkatan komponen teknik, taktik dan mental.

Kondisi fisik harus dilatih dengan porsi yang lebih banyak pada waktu awalawal latihan. Harsono (1988:154) mengemukakan bahwa :...banyak tekanan harus diberikan pada perkembangan itu secara keseluruhan yang secara teratur harus ditambah intensitasnya. Dalam preseason, yaitu musim latihan jauh sebelum pertandingan, berbagai komponen kondisi fisik harus dilatih agar pada waktu atlet memasuki musim-musim latihan berikutnya yaitu early dan mid season, dia sudah mencapai kondisi fisik yang baik.

Hal ini disebabkan karena latihan fisik merupakan dasar bagi latihan teknik, taktik, dan mental. Latihan teknik apabila tidak didukung oleh kondisi fisik yang yang baik akan menimbulkan penguasaan teknik yang tidak sempurna, karena dengan kondisi fisik yang jelek seseorang yang mempelajari suatu teknik dalam jangka 
waktu yang lama akan cepat merasakan kelelahan, sehingga teknik yang dilatih tidak dikuasai dengan sempurna.

Kondisi fisik terdiri dari bermacammacam komponen, antara lain adalah daya tahan, kecepatan, kekuatan, kelentukan, power, stamina, dan kelincahan. Semua jenis kondisi fisik tersebut dapat ditingkatkan dengan berbagai bentuk latihan, demikian pula dengan komponen kondisi fisik power. Power tungkai sangat penting untuk dilatih karena tungkai merupakan bagian tubuh yang amat penting, berperan besar dalam menopang tubuh manusia, juga dalam setiap cabang olahraga tungkai memiliki peranan penting dalam mencapai prestasi yang optimal. Peningkatan kemampuan komponen kondisi fisik semakin berkembang seiring dengan pertumbuhan dan peningkatan usia seseorang. Komponen kondisi fisik ini dapat ditingkatkan dengan berbagai macam bentuk latihan antara lain adalah weight training, dan plyometric.

Plyometric merupakan salah satu bentuk latihan yang ditujukan untuk meningkatkan kondisi fisik berupa kemampuan daya ledak (eksplosif) otot. Harsono (2001:41) mengemukakan bahwa, “Cara yang paling baik untuk memperkembang power maksimal pada suatu kelompok otot tertentu adalah dengan meregangkan (memanjangkan) terlebih dahulu otot-otot tersebut
(Kontraksi eksentrik), sebelum mengkontraksi (memendekan) otot-otot itu secara eksplosif (Kontraksi konsentrik).”

Maksud kalimat tersebut adalah karakteristik latihan pliometrik untuk menambah penyediaan energi elastis otot selama kontraksi konsentrik dalam gerakan, maka terlebih dahulu menggerakan otot ke arah yang berlawanan dalam upaya mengerahkan tenaga untuk kontraksi konsentrik.

Tuntutan berprestasi pada anak usia Sekolah Menengah Pertama (SMP) dengan adanya Olimpiade Olahraga Siswa Nasional (OOSN) merupakan sebuah tantangan bagi guru penjaskes di sekolah, karena dalam hal pembinaan kondisi fisik pada siswa terkadang terabaikan dibandingkan dengan keterampilan yang di utamakan. Faktor kondisi fisik yang dominan dalam penentuan kegiatan dalam cabang olahraga adalah power tungkai, karena tungkai merupakan penopang tubuh dalam setiap aktivitas. Pengembangan otototot tungkai yang lemah pada siswa-siwa usia sekolah menenga bisa dilakukan tidak harus dengan angkat beban melainkan juga dengan bentuk latihan pliometrik, yang mana latihan-latihan pliometrik semua bisa dilakukan di sekolah dan tidak memerlukan biaya yang lebih mahal .

Proses pengembangkan prestasi di sekolah dalam olahraga harus pula didukung dengan proses latihan 
pengembangan kondisi fisik sebagai dasar penunjang keberhasilan berlatih dalam komponen yang lain, kaitannya dengan penelitian ini penulis merasa tertarik untuk mengkaji masalah tentang perbandingan pengaruh latihan lari melewati bilah dan lari angkat paha terhadap peningkatan power tungkai siswa SMP Negeri 3 Kawali

\section{METODE}

\section{Partisipan dan Prosedur Pengambilan Sampel}

Metode eksperimen ini sangat cocok digunakan dalam penelitian ini, sebab proses latihan melewati bilah dan lari angkat paha terhadap peningkatan power tungkai siswa SMP Negeri 3 Kawali. Akhir dari penelitian yang penulis lakukan adalah melakukan uji statistik kuantitatif melalui angka-angka yang dihasilkan dari pengukuran hasil eksperimen.

Penelitian ini menggunakan populasi siswa putra kelas VIII SMP Negeri 3 Kawali, sebanyak 58 orang. Jumlah populasi tersebut di atas diambil 30 orang untuk dijadikan sampel. Penulis mengambil secara acak dari jumlah populasi untuk dijadikan sampel (random sampling), adapun cara pengambilan jumlah sampel dari tiap kelas dapat dilihat pada tabel di bawah ini:

\begin{tabular}{cccc}
\multicolumn{3}{l}{ Tabel 1 Pengambilan Sampel } \\
\hline Kelas & Jumlah & Penghitunga & Siswa \\
& Siswa & $\mathrm{n}$ & Sampe \\
& Putra & & 1 \\
\hline
\end{tabular}

\begin{tabular}{cccc}
\hline VIII 1 & 14 & $50 \% \times 13=6,50$ & 7 \\
VIII 2 & 14 & $50 \% \times 13=6,50$ & 7 \\
VIII 3 & 16 & $50 \% \times 18=9,00$ & 9 \\
VIII 4 & 14 & $50 \% \times 14=7,00$ & 7 \\
Jumlah & 58 & & 30 \\
\hline
\end{tabular}

Alat ukur yang digunakan dalam penelitian ini adalah Standing Broad Jump, yang diadaptasikan dari pedoman tes dan pengukuran olahraga, Nurhasan (1994:87) Lebih jelasnya penulis akan menguraikan prosedur dan peralatan yang diperlukan dalam pelaksanaan pengukuran power otot tungkai dengan Standing Broad Jump sebagai berikut: 1. Alat /fasilitas yang dibutuhkan seperti Lapangan lompat jauh atau matras, Formulir pencatatan hasil tes. 2. Pelaksanaan tes: a. Testee berdiri pada papan tolak atau garis yang di buat, badan dan tungkai dibungkukkan. Kedua lengan diluruskan ke depan. b. Kemudian testee menolak untuk melompat, dengan menolakan kedua tungkai sehingga akan menghasilkan lompatan yang jauh. c. Mendarat dengan kedua kaki rapat, titik berat badan dibawa ke depan dengan cara menekuk kedua lutut. 3. Penskoran. Skor dari tes power otot tungkai dengan standing broad jump yang di catat adalah jarak yang dicapai, yaitu dengan cara mengukur dari titik terdekat pada saat mendarat ke titik awal pada awal melakukan lompatan.

\section{HASIL DAN PEMBAHASAN}

Hasil 
Hasil penghitungan nilai rata-rata $(\mathrm{X})$ dan simpangan baku (S) tersebut dapat dilihat pada Tabel 2.

Tabel 2 Deskripsi Data

\begin{tabular}{ccccccc}
\hline \multirow{2}{*}{ Latihan } & \multicolumn{2}{c}{ Tes Awal } & \multicolumn{2}{c}{ Tes Akhir } & \multicolumn{3}{c}{$\begin{array}{c}\text { Peningkata } \\
\text { n }\end{array}$} \\
\cline { 2 - 7 } & $\bar{x}$ & $\mathrm{~S}$ & $\bar{x}$ & $\mathrm{~S}$ & $\bar{x}$ & $\mathrm{~S}$ \\
\hline $\begin{array}{c}\text { Lari } \\
\text { Lewati } \\
\text { bilah }\end{array}$ & 142,2 & 15,78 & 163,8 & 23,43 & 21,6 & $\begin{array}{c}7,9 \\
9\end{array}$ \\
\hline $\begin{array}{c}\text { Lari } \\
\text { Angkat } \\
\text { Paha }\end{array}$ & 142,5 & 15,70 & $\begin{array}{c}158,8 \\
7\end{array}$ & 22,61 & 17,6 & $\begin{array}{c}7,6 \\
7\end{array}$ \\
\hline
\end{tabular}

Data penghitungan uji normalitas data tiap variabel dapat dilihat pada Tabel. di bawah ini.

Tabel 3 Hasil Uji Normalitas

\begin{tabular}{lccc}
\hline $\begin{array}{c}\text { Kelompok } \\
\text { Latihan }\end{array}$ & L- hitung & L-Tabel & Kesimpulan \\
\hline Kelompok & & & \\
A : Tes awal & 0,1127 & 0,220 & Normal \\
Tes akhir & 0,0729 & 0,220 & Normal \\
\hline Kelompok B & & & \\
: Tes awal & 0,1122 & 0,220 & Normal \\
Tes akhir & 0,0884 & 0,220 & Normal \\
\hline
\end{tabular}

Hasil penghitungan uji homogenitas dapat dilihat pada Tabel di bawah:

Tabel 4 Hasil Uji Homogenitas

\begin{tabular}{lccc}
\hline \multicolumn{1}{c}{ Variansi } & F-hitung & F-tabel & Kesimpulan \\
\hline $\begin{array}{l}\text { Tes awal dan } \\
\text { tes akhir } \\
\text { kelompok A }\end{array}$ & 2,20 & 2,48 & Homogen \\
\hline $\begin{array}{l}\text { Tes awal dan } \\
\text { tes akhir } \\
\text { kelompok B }\end{array}$ & 2,07 & 2,48 & Homogen \\
\hline
\end{tabular}

Hasil penghitungan tersebut dapat dilihat pada Tabel.
Tabel 5 Hasil Uji Peningkatan

\begin{tabular}{cccc}
\hline $\begin{array}{c}\text { Kelompok } \\
\text { Latihan }\end{array}$ & t-hitung & t-tabel & Kesimpulan \\
\hline $\begin{array}{c}\text { Lari } \\
\text { Melewati } \\
\text { Bilah }\end{array}$ & 3,06 & 1,70 & Signifikan \\
\hline $\begin{array}{c}\text { Lari } \\
\text { Mengangkat } \\
\text { Paha }\end{array}$ & 2,27 & 1,70 & Signifikan \\
\hline
\end{tabular}

Hasil penghitungan dan pengujian tersebut akan diketahui apakah ada perbedaan hasil peningkatan kemampuan power tungkai tersebut signifikan atau tidak signifikan. Hasil penghitungan dapat dilihat pada tabel.

Tabel 6 Hasil Perbedaan Peningkatan Kelompok

\begin{tabular}{cccc}
\hline $\begin{array}{c}\text { Kelompok } \\
\text { Latihan }\end{array}$ & $\begin{array}{c}\mathrm{t}- \\
\text { hitung }\end{array}$ & $\begin{array}{c}\mathrm{t}- \\
\text { tabel }\end{array}$ & Keterangan \\
\hline $\begin{array}{c}\text { Lari Melewati } \\
\text { Bilah }\end{array}$ & 1,35 & 1,70 & $\begin{array}{c}\text { Tidak } \\
\text { Signifikan }\end{array}$ \\
$\begin{array}{c}\text { Lari Mengangkat } \\
\text { Paha }\end{array}$ & & & \\
\hline
\end{tabular}

\section{Pembahasan}

Beberapa pakar olahraga merekomendasikan bahwa, selain dengan latihan beban (weight training) yang khusus untuk meningkatkan kekuatan dan kecepatan, metode latihan yang lebih mengarah kepada pengembangan power/daya ledak adalah dengan cara mendesain alat latihan dengan adanya beban latihan. Secara sederhana untuk proses latihan di sekolah-sekolah bisa menggunakannya beban latihan yang di modifikasi. Pemilihan sistem dan bentuk latihan yang tepat merupakan salah satu 
faktor penentu keberhasilan dari proses latihan dalam pencapaian prestasi.

Upaya dalam meningkatkan power tungkai terlebih dahulu diperlukan kekuatan (Strenght), karena kekuatan merupakan dasar pembentukan power. Mengenai hal ini Harsono (1988:200) mengemukakan, "Strength tetap merupakan dasar (basis) untuk pembentukan power”. Hidayat (1999:67) mengemukakan, "Kekuatan adalah gaya yang ditimbulkan oleh kontraksi otot, Kontraksi dapat diterjemahkan dengan tegangan atau pengerahan kekuatan yang dihasilkan oleh serabut-serabut otot". Sedangkan latihan untuk memperoleh kekuatan adalah latihan tahanan.

Latihan pliometrik menggunakan kekuatan gaya gravitasi untuk menambah penyediaan energi elastis otot selama kontraksi eksentrik (fase persiapan) dalam gerakan, dapat penulis simpulkan bahwa latihan beban merupakan suatu bentuk latihan tahanan dengan menggunakan beban luar atau eksternal resistence, sedangkan latihan loncatan dengan rintangan dan tanpa rintangan merupakan latihan pliometrik yang bebannya adalah tubuh.

Latihan tahanan melalui bentuk latihan lari melewati bilah dan lari angkat paha merupakan salah satu bentuk latihan untuk meningkatkan power dalam bentuk kontraksi isotonis. Hidayat (1999:71) mengemukakan, "Dalam kontraksi isotonis bila bebannya ringan sekali, otot dapat memendek dengan cukup nyata dan cepat.” Kaitannya dengan latihan beban untuk melatih power tidak hanya menekankan pada beban, akan tetapi harus pula pada kecepatan. Harsono (1988:200) menjelaskan bahwa: "Latihan power tidak boleh hanya menekankan pada beban, akan tetapi harus pula pada kecepatan mengangkat, mendorong, atau menarik beban. Oleh karena harus mengangkat dengan cepat, maka dengan sendirinya berat bebannya tidak seberat latihan untuk latihan kekuatan. Akan tetapi juga tidak boleh terlalu ringan sehingga otot tidak merasakan rangsangan beban."

Modifikasi latihan kekuatan dan kecepatan melalui latihan lari melewati bilah dan lari mengangkat paha dalam penelitian ini memberikan pengaruh yang signifikan terhadap peningkatan power tungkai pada siswa SMP Negeri 3 Kawali. Berdasarkan hasil pengolahan data diperoleh pengaruh yang signifikan dari kedua proses latihan. Namun bentuk latihan lari melewati bilah dan latihan lari mengangkat paha bukan satu-satunya faktor penentu keberhasilan dalam sebuah latihan pengembangan power tungkai. Masih banyak faktor penentu dari suatu program dan bentuk latihan yang lain, sehingga perlu untuk diperhatikan agar proses latihan dapat efektif dan efisien. 


\section{KESIMPULAN}

Berdasarkan hasil pengolahan dan analisis data dari penelitian yang penulis lakukan melalui suatu pengukuran terhadap sampel, maka penulis dapat mengambil beberapa kesimpulan sebagai bagian akhir dari proses penelitian sebagi berikut :1. Latihan lari melewati bilah memberikan pengaruh yang signifikan terhadap peningkatan power tungkai pada siswa SMP Negeri 3 Kawali. Hal ini terbukti dengan diperolehnya hasil penelitian, yang menunjukkan bahwa latihan lari melewati bilah memiliki nilai $\mathrm{t}$ hitung 3,06 lebih besar daripada t-tabel $(1,70)$ pada tingkat kepercayaan 0,05 dengan $d k=n 1+n 2-2=28$. 2. Latihan lari mengangkat paha memberikan pengaruh yang signifikan terhadap peningkatan power tungkai pada siswa SMP Negeri 3 Kawali. Hal ini terbukti dengan hasil penelitian, proses latihan lari mengangkat paha memiliki nilai $\mathrm{t}$ hitung 2,27 lebih besar daripada t-tabel $(1,76)$ pada tingkat kepercayaan 0,05 dengan $\mathrm{dk}=\mathrm{n} 1+\mathrm{n} 2-2=$ 28. 3. Tidak terdapat perbedaan pengaruh antara latihan lari melewati bilah dengan lari mengangkat paha terhadap peningkatan power tungkai pada siswa SMP Negeri 3 Kawali, dimana hasil penghitungan dan uji signifikansi dengan menggunakan uji rata-rata dua pihak yaitu uji-t, diperoleh t-hitung 1,35 yang lebih kecil dari t-tabel $(1,70)$ pada tingkat kepercayaan 0,95 dengan $\mathrm{dk}=28$.

Hasil dari penelitian dapat disimpulkan bahwa tidak ada hubungan antara pengeluaran energi (METs) aktivitas fisik dengan BMI pada anak usia dini.

\section{REFERENSI}

Arikunto Suharsimi, (2005), Manajemen Penelitian. Jakarta, PT. Rineka Cipta

Harsono, (1988), Coaching dan Aspekaspek Psikologis dalam Coaching, Jakarta. Tambak Kusumah.

, (2001). Latihan Kondisi Fisik. Modul Penyegaran atau penataran para pelatih olahraga. Bandung.

Hidayat Imam, (1999). Biomekanika. FPOK IKIP, Bandung.

Lumintuarso Ria, (2009). Peralatan Olahraga Anak untuk Pengembangan Multilateral. DIRJEN DIKDAS. Jakarta.

Nurhasan, (1994). Tes dan Pengukuran dalam Pendidikan Jasmani, Prinsip-prinsip dan penerapannya. FPOK IKIP. Bandung.

Notoatmodjo Soekidjo, (2005). Metodologi Penelitian Kesehatan, PT Rineka Cipta. Jakarta.

Poerwadarminta, W.J.S. (1982), Kamus Bahasa Indonesia, Balai Pustaka. Jakarta

Saputra M Yudha (2001), Pendekatan Bermain untuk Sekolah Lanjutan Pertama. Direktorat Jendral Dikdasmen. Jakarta. 
Sudjana (1996). Metode Statistika, Tarsito. Bandung.

Sudrajat Jajat, (2005). Pendidikan Jasmani. Yudhistira, Surakarta.

Sugiyanto, (1993). Perkembangan Gerak. DEPDIKBUD DIKDAS. Jakarta.

Sugiyono, (2009). Metode Penelitian Pendidikan, Alfabeta. Bandung.

Supandi dan Seba, Laurens, (1993), Teori Belajar-Mengajarkan Motorik. Diktat, FPOK-IKIP Bandung.

Supandi, (1991). Landasan Ilmiah Olahraga. Kerjasama ITB dan FPOK IKIP Bandung.

Suherman Adang, (2001), Menuju Perkembangan Menyeluruh, Jakarta. DIRJEN DIKDASME.

Umar Husein, (2005). Metode Penelitian Untuk Skripsi dan Tesis Bisnis. PT. Raja Grafindo Persada, Jakarta. 